Article

\title{
Accountability in EU Economic Governance: European Commissioners in Polish Parliament
}

\author{
Tomasz P. Woźniakowski \\ Hertie School, Germany; E-Mail: wozniakowski@hertie-school.org \\ Submitted: 1 April 2021 | Accepted: 3 June 2021 | Published: 13 August 2021
}

\begin{abstract}
This article analyses the interactions between the members of the Polish parliament with the European commissioners in the context of the European Semester, the annual cycle of economic coordination. The Commission drafts crucial documents in this process which assess the implementation of the Country Specific Recommendations (CSRs): the Annual (Sustainable) Growth Survey and the Country Reports. The goal of this article is to assess how the Commission is held to account by a national parliament and how this affects the level of implementation of CSRs. The findings suggest that the Commission is accountable to this national parliament, even if the form of accountability taken is rather innovative and its policy impact limited, at both the EU (the CSRs tend to be immune to Members of [national] Parliament's contestation) and the national level, as the implementation of CSRs seems to be independent of the level of their scrutiny.
\end{abstract}

\section{Keywords}

CSRs; European Semester; EU accountability; EU economic governance; national parliaments; Sejm

\section{Issue}

This article is part of the issue "Rising to a Challenge? Ten Years of Parliamentary Accountability of the European Semester" edited by Eric Miklin (University of Salzburg, Austria), Aleksandra Maatsch (University of Wroclaw, Poland) and Tomasz P. Woźniakowski (Hertie School, Germany).

(C) 2021 by the author; licensee Cogitatio (Lisbon, Portugal). This article is licensed under a Creative Commons Attribution 4.0 International License (CC BY).

\section{Introduction}

The euro crisis led to the introduction of a number of institutional changes in the economic and fiscal surveillance of the EU-the European Semester-which represent much more fundamental shifts than merely enhancing existing rules to make them more enforceable. In particular, it gave a number of EU institutions a large 'discretionary space' to intervene in the domestic policymaking of the member states and consequently created an accountability deficit at the EU level (Dawson, 2015). Importantly, this space includes not only the level of indebtedness but also recommendations on virtually all other policies, such as taxation, social protection, and public health. However, the problem with these Country Specific Recommendations (CSRs) is their very low implementation rate (Darvas \& Leandro, 2015). The European Commission has tried to address this problem by engaging with national parliaments (NPs) and thus increas- ing 'ownership.' Indeed, it has been demonstrated that among its three forms, the cognitive ownership is particularly relevant in the context of the commissioners' visits in the NPs (the two other being institutional and political ownership): "Whereas institutional ownership by the NPs seems low, meetings organized with the EU administration as well as the newly introduced 'Semester visits' from commissioners have raised the cognitive ownership of the process among members of national parliaments" (Vanheuverzwijn \& Crespy, 2018, p. 589). Some scholars also suggested that hearings in the NPs' joint committees with the relevant commissioner discussing CSRs and other relevant documents could be one option for 'an enhanced European Semester':

Strengthen national parliamentary scrutiny over the European Commission: Parliamentary committees could invite representatives of the European Commission to discuss the Annual Growth Survey. 
More ambitiously, a hearing with the responsible commissioner or Commission Vice-President would take place before a joint committee meeting and he or she would have to present and justify CSRs as well as assess the progress of government in their implementation. (Kreilinger, 2016, p. 57)

Moreover, it has been claimed that "greater parliamentary accountability should eventually contribute to the collective ownership of the European Semester" (Crum, 2018 , p. 283) and that the 'legitimacy' of the Semester is positively related to its 'efficiency,' i.e., the implementation rate of the CSRs (Hagelstam et al., 2018). It seems to support the claim made by the European Parliament, which in its resolution on the Annual Growth Survey (AGS) in 2018 stated that it "believes that more national ownership through genuine public debates at the national level would lead to better implementation of the CSRs; considers it important to ensure that national parliaments debate country reports and CSRs" (European Parliament, 2018, p. 9). However, as the authors themselves admit, a causal link has yet to be established:

At Member State level, drawing a clear link between the degree of national parliamentary involvement and the CSRs' implementation rate seems to [be] more difficult, probably due to the fact that the implementation rate depends on many factors (of which the degree of parliamentary involvement is only one). (Hagelstam et al., 2018, p. 21)

Moreover, questions remain as to the exact form this involvement takes, the implications for the Commission's accountability, and the actual policy effects of the 'genuine public debates at national level.' This article aims to address some of those issues.

This article builds on the findings of Hallerberg and colleagues (2018), who demonstrated that non-euro parliaments scrutinize the European Semester more closely than those in the euro countries. By offering an in-depth analysis on the content of parliamentary hearings on the European Semester, this article sheds light on the role of parliaments in holding the supranational executive to account in the EU's economic governance. The accountability of governments to NPs in the EU has been discussed in the literature for decades (e.g., Hefftler et al., 2015; Maurer \& Wessels, 2001). Earlier work focused on accountability across levels and parliaments (e.g., Benz, 2006, 2013; Kohler-Koch \& Rittberger, 2007; Lord, 2014; Schmidt, 2004). Most recently, Fabbrini employed a comparative federalism perspective to demonstrate that "EU executive power is thus like a two-headed elephant. The Commission-head is institutionally accountable but on issues of low domestic political salience, while the European Council-head is institutionally unaccountable on issues of high domestic political salience" (Fabbrini, 2021, p. 13). However, the research on how the EU institutions can be held to account at the national level, especially on issues of high political salience, is scarce (but see Crum \& Oleart, 2020; Fromage, 2017; Tesche, 2019). Moreover, the literature using accountability frameworks has focused on EU affairs in general (Auel, 2007; Auel et al., 2015; Bergman \& Damgaard, 2000; Bergman et al., 2003; Jancic, 2011; MacCarthaigh, 2007; Raunio, 2001; Wouters \& Raube, 2012). By contrast, this article studies accountability in economic policy, offering an in-depth analysis of this crucial field. The available empirical research regarding parliamentary accountability of economic governance is rather scarce and tends to be limited both when it comes to scope and timeframe (but see Auel \& Höing, 2014; Jancic, 2016; Maatsch, 2017a, 2017b; Schweiger, 2021; Serowaniec, 2016, pp. 195-199, 263-264). Furthermore, many comparative studies on the engagement of NPs in EU economic governance or the European Semester tend to include the eurozone members only (Fasone, 2015, 2018; Haas et al., 2020; Pernice, 2017) even though the European Semester concerns all EU countries, including the 'new member states' which joined in 2004-2007 and since then its "domestic politics... has more leeway to shape-and limit-the Europeanization process" (Woźniakowski et al., 2018, p. 8). By exploring the debates on the crucial documents of economic governance, the AGS and Country Reports in which the assessment of the implementation of the CSRs is provided, I help to close this gap in the literature.

In analysing the questions asked by the members of parliament (MPs), I focus particularly on those related to the CSRs. The focus on CSRs has several advantages: First, as the CSRs constitute the most important (and intrusive) element of the Semester for national legislatures and was perhaps the main reason behind its introduction, analysing the level of CSRs' scrutiny allows to draw conclusions about the legitimacy of the process as a whole. Second, the analysis of the specific questions about the CSRs allows one to not only see how but also why certain recommendations are contested. Third, I will also try to test a hypothesis that CSRs with a higher ownership level are more likely to be implemented. In so doing, I group the CSR-related questions in a given year according to the sub-recommendations (each CSR usually contains several specific policy recommendations) and their implementation in the following year. Hence, I divide each CSRs into subcategories, the implementation of which is assessed by the Commission in the Country Reports.

This article will be structured as follows. In the second Section, "Analytical Framework," I discuss the definition of accountability and my method. This is followed by Section 3, "Empirics," in which the hearings are examined. Section 4 concludes.

\section{Analytical Framework}

Including information as a part of an accountability chain recognizes the fact that fora are not unitary 
actors and that some groups within them are likely to exercise their accountability rights by a demand for information only. Contrary to what scholars used to believe (the so-called 'old dualism,' for instance of parliaments versus governments), a forum is composed of at least two different groups ('new dualism'; Auel, 2007, p. 487), depending on the scrutinized issue, of those contesting (opponents) and those justifying (proponents). In the case of NPs, the most fundamental distinction is between the parliamentary majority and government on the one hand, and the opposition on the other. While the former group tends to publicly demand information only and challenge/demand change or sanction of the actor through informal channels (informal meetings, intra-party groups, etc.), the latter is more likely to contest/challenge the conduct of the actor publicly.

According to Auel, such an acknowledgement of the fact that parliaments are divided allows for the recognition of different forms of scrutiny that the two parliamentary groups are likely to perform (Auel, 2007, p. 487). Consequently, she introduces two elements of accountability (monitoring and political scrutiny) which correspond to the first two steps of the process. Moreover, for each step, a different parliamentary group is primarily 'responsible.' Consequently, monitoring scrutiny is the element of accountability which is conducted in the first stage and is "an important part of, and a prerequisite to, full accountability" (Auel, 2007, p. 500). Within this element (and stage) an "agent is obliged to inform the principal about his (planned) behaviour and actions, by providing information on the performance of tasks, on procedures and outcomes" in order to reduce 'information asymmetries.' Significantly, without adequate information, one cannot speak about full accountability. Indeed, the role of this first step of 'monitoring scrutiny' is to demand information and this stage is likely to be executed by those with the parliamentary majority. Certainly, it is unrealistic to expect this group to challenge the government publicly, if this is the actor that is held to account.

However, the second stage (political scrutiny) is usually performed by the parliamentary opposition and this is when the government's conduct is challenged and contested in public. This is the stage when the assessment and judgment of the 'appropriateness of the government's decision' takes place. This element of accountability is exercised by using various forms such as "parliamentary questions and public debate" (either in the committees or in the plenary), which allows for "assessing and criticizing the government's actions" (Auel, 2007, p. 500). By building on this work, Woźniakowski, Maatsch, and Miklin, in the Introduction to this Issue (2021, p. 97), distinguished two forms of accountability: "1. Justification, or the lighter form of accountability, including questions demanding information and explanation; 2. Contestation, or the heavier form of accountability, including statements of disagreement, requests for change, and sanctions." Consequently, this conceptual model offers a lower and upper limit of accountability, corresponding to its two basic forms:

a) Lower limit of accountability: the presence of Commission representatives at the NPs hearing in which the questions asked demand information and explanation and therefore fall within the justification form of accountability;

b) Upper limit of accountability: the questions asked during hearings demand change, sanctions, or express disagreement and therefore fall within the contestation form of accountability.

In contrast to the definition of Bovens and colleagues who claim that "[a]ccountability is furthermore a retrospective ex-post-activity" (Bovens et al., 2014, p. 6), I argue instead that the most valuable form of accountability is ex-ante (Eriksen \& Katsaitis, 2020). This is the only time when the forum can not only sanction the actor for bad conduct but also prevent it from happening in the first place, potentially reducing reputational costs (Busuioc \& Lodge, 2016). Indeed, as Auel notes, such monitoring and scrutiny of governments is particularly important in "European policy making, as national parliaments, or more specifically, the majority parties, are not directly involved in decision making at the European level" (Auel, 2007, p. 498).

Importantly, a few scholars working on the role of NPs in the EU use the framework of accountability (but see, e.g., Barrett, 2015; Crum, 2018). Existing studies have not been able to capture the essence of accountability mechanisms because they did not follow an approach that emphasizes the substance of interactions. By contrast, I focus on the substance of the exchanges between an actor (the Commission) and a forum (lower chamber of the Polish parliament, the Sejm) in the accountability chain. I divided these interactions into falling within the scope of the abovementioned two forms of accountability, as shown in the following section. While this analytical framework is admittedly more appropriate for an analysis of 'regular' accountability mechanisms between parliamentarians and the members of government, I believe that it is still useful in examining commissioners visits in the NPs as "an innovative form of accountability of EU decision-making" (Crum \& Oleart, 2020, p. 6).

\section{Empirics}

Clearly, the forum to which the Commission is accountable is the European Parliament. Nevertheless, the Two-Pack provided an opportunity for the eurozone countries to invite a commissioner to NPs in order to discuss different elements of the European Semester, but few eurozone countries have used this opportunity. In fact, it has been demonstrated that the non-euro states scrutinize the Semester more than the euro members (cf. Hallerberg et al., 2018). By conducting an in-depth 
case study of the largest non-eurozone country, I build on this previous research and aim to examine how the Commission is held to account by the Polish parliament and how this affects the implementation level of the CSRs.

I examined all hearings held by the Sejm with the European commissioners in the context of the European Semester in the first decade since its introduction (2011-2020). There were six such hearings in total: Four were held with Janusz Lewandowski, then Budget and Financial Programming Commissioner (2010-2014), during the seventh term of the Sejm, when Civic Platform (PO) and Polish People's Party (PSL) formed a governing coalition; and two were held with Valdis Dombrovskis, then Vice-President of the European Commission (2014-2019) responsible for the Euro, Social Dialogue, and the Financial Stability, Financial Services, and Capital Markets Union, during the eighth term of Sejm, when Law and Justice (PiS) held power. I focus on committee hearings in the lower chamber of the Polish parliament, the Sejm, because it is here, and not the plenary, where the European Semester is scrutinized. The four hearings with Lewandowski took place in 2013 and 2014 and concerned two types of document drafted by the Commission: the AGS discussed on 22 February 2013 (Sejm, 2013a) and 10 January 2014 (Sejm, 2014a); and CSRs for Poland, debated on 7 June 2013 (Sejm, 2013b) and 5 June 2014 (Sejm, 2014b). However, the accountability mechanisms exercised during those hearings were quite blurred for two reasons. First, during the winter cycles in both 2013 and 2014, when the AGS was debated, not only the Polish MPs but also Members of the European Parliament (MEPs) took an active part and asked questions of the commissioner. Secondly, during the spring cycles of the Semester (in 2013 and 2014), when the CSRs were discussed, not only the commissioner but also ministers from the government were questioned. As a result, it was often difficult to distinguish questions addressed to the commissioner from those directed towards members of the government. For these reasons, and given the limited space of an article format, I decided to focus on the remaining hearings with Valdis Dombrovskis, as those were representative for the purpose of illustrating innovative accountability mechanisms between the European Commission and NP and their impact on policy-making.

The first hearing on the AGS and Country Report 2017 took place on 9 March 2017 (Sejm, 2017) at a joint session of three of the Sejm's committees: Public Finances, Economy and Development, and European Union Affairs. It was chaired by Izabela Kloc of the governing PiS party, chair of the European Union Affairs Committee. Dombrovskis presented detailed information about both documents, including the Commission's work plan regarding financial and economic issues, and an assessment of the implementation of CSRs in Poland. This found that Poland had made limited progress, with the second-lowest score on a scale of 1 to 5 . As stated by the commissioner, this was in line with the EU aver- age of 1-2. Afterwards, he answered three rounds of questions from the MPs. Nine MPs (six from PiS, three from the opposition: one from $\mathrm{PO}$, and two from the Modern party [N]) asked 21 questions in total. The commissioner came to Warsaw again one and a half years later (23 November 2018) to discuss the next cycle of the Semester (Sejm, 2018). Importantly, his visit was organized just after the release of the AGS and Work Program, but before the publication of the Country Report. Thus, this hearing did not concern the Report, where-inter alia-the assessment of the CSRs is included. However, in his introductory remarks, Dombrovskis did outline the CSRs that the Commission had issued for Poland in May, in addition to outlining the economic situation in Europe, the priorities of the Commission's economic policy for the next year, and the assessment of the economic situation in Poland. The debate which followed had four rounds of questions and, similar to the debate from March in the previous year, there was a joint session of the EU and the two sectoral committees. This time, the head of the Public Finance Committee, Andrzej Szlachta (PiS) chaired the hearing, in which 18 questions were asked in total. Although the hearings took place in both 2017 and 2018, the AGS of 2018 was not debated, as only the 2017 and 2019 cycles of the European Semester were subject to hearings with the commissioner. On 26 March 2018, the committees of EU affairs and Public Finance had a hearing with Günther Oettinger about the future EU budget and the Commission's work plan, and this may explain the lack of debate about the European Semester in the 2018 cycle.

The analysis shows a clear difference between the two hearings due to their timing: While in the hearing from March 2017 both the AGS and Country Report (the 2017 cycle of the Semester), which assessed the implementation of the CSRs were subject to the debate, the meeting from November 2018 (the 2019 cycle of the Semester) concerned only the AGS because the Country Report is published later on in the process, in February. This creates a clear trade-off for parliamentarians on when to invite the commissioner. Holding the hearing early in the process, i.e., in the autumn, enables them to gather information that could be used later on in the process of scrutinizing the Semester (e.g., during the debates on Convergence and National Reform Programmes with the members of the government). It may potentially allow them to influence how the socioeconomic situation of Poland will be assessed by the Commission in the Country Report, for example allowing for ex-ante scrutiny. On the other hand, there is a clear advantage to also debating the Country Report, as it constitutes the most detailed analysis of the country, including the most controversial issues, such as the assessment of the implementation of the CSRs.

How does the exercise of this innovative form of accountability fit the analytical framework? Around half of the questions raised demanded information and the other half were almost equally divided between requests 
for justification and acts of contestation (mainly expressions of disagreement) of the Commission's conduct. Hence, three-quarters of questions reached the lower limit of accountability; and one-quarter, its upper limit, as defined in Section 2. When it comes to the CSR-related interactions, there were five questions about the CSRs of 2016 that were asked about during the 2017 hearing. Out of the 21 asked in total, three of them requested information/explanation (justification form of accountability) and in two questions the MPs criticized the CSRs (contestation, i.e., the 'heavier' form of accountability). The progress of those CSRs was assessed in the Country Report 2017, which was the subject of the hearing and the overall evaluation was limited progress' (on a scale: no-, limited-, some-, substantial progress, full implementation). However, the details of the assessment of each CSR as well as sub-CSRs are provided below. In the 2018 hearing, nobody asked a question related to the CSRsthis may be explained by the timing of the hearing, as explained earlier.

\subsection{Justification}

A question related to a part of CSR1 (i.e., "Strengthen the fiscal framework, including by establishing an independent fiscal council"), on the role of a fiscal council, was asked by Marcin Święcicki from PO, who was wondering what the competencies of such a council could be, how it could impact the decisions regarding, for instance, retirement age, the countries in which it exists, and about the arguments in favour of creating such a council. Dombrovskis provided a detailed answer stressing that such a council would produce an independent budgetary forecast and provide advice to the government, which would strengthen the fiscal framework of a member state. The implementation of CSR1 was assessed as 'limited progress' overall, but no progress with this specific sub-recommendation concerning a fiscal council (European Commission, 2017, p. 14). Even though this issue was not contested in the parliament, and perhaps because both the $\mathrm{PO}$ and PiS governments failed to create a fiscal council, the Commission dropped this sub-CSR in the following year.

The next question did not concern any particular CSR, but the overall system of recommendations. Namely, the same opposition MP (Święcicki) asked how the Commission could influence countries which do not implement recommendations, such as Poland, which ignored the CSR regarding retirement age. He asked whether the instruments that the Commission has at its disposal to encourage or force countries to implement the CSRs were sufficient and if it would use different instruments for eurozone and non-eurozone countries. In the light of the fact that the implementation record is limited in most EU states, he asked if the Commission should have stronger enforcement instruments. Dombrovskis provided a detailed answer in which he stressed that the CSRs are not injunctions, but only recommendations, and therefore the Commission does not have any mechanisms to enforce them. In the Commission's view, he stressed, the main means to ensure that recommendations are implemented are dialogue with NPs parliaments and promotion of the Commission's agenda to assure member states that its recommendations are beneficial for them.

The third question related to a sub-recommendation of CSR1 ("Improve tax collection by ensuring better VAT compliance"). Wojciech Zubowski (PiS) was quite specific and asked about the Commission's plans regarding the VAT gap. After praising the fact that the Commission appreciated Polish efforts in fighting VAT evasion, he asked about its plans in fighting such white-collar crimes. Indeed, the Commission assessed that 'some progress' had been made in "ensuring better tax compliance" (European Commission, 2017, p. 14). Dombrovskis replied that this was a priority of the Commission, which works on this issue within, for instance, OECD programs on the erosion of the tax base. Regarding the VAT gap, he praised the Polish authorities for making some progress in this matter and promised to work closely together on tax evasion. He added that taxes should be paid in the country where the economic activity is conducted and not where taxes are the lowest. In the next year's CSR, this sub-recommendation was dropped, even if its implementation was assessed as 'some progress' in the 2017 Country Report.

\subsection{Contestation}

Two questions were clearly contesting CSR2 ("Ensure the sustainability and adequacy of the pension system and increase participation in the labour market, by starting to reform the preferential pension arrangements, removing obstacles to more permanent types of employment and improving the labour market-relevance of education and training"). Both were asked by PiS MPs and concerned a CSR, the implementation of which in the Country Report was assessed as 'no progress,' both overall and for every sub-recommendation. Moreover, it noticed that "key measures in the legislative process go in the opposite direction" (European Commission, 2017, p. 14). The two questions were asked about the lowering of the statutory retirement age, which entered into force in October 2017. Jan Mosiński (PiS) criticized the commissioner's assessment that the lowering of the statutory retirement age, a reversal of the previous reform, would have a negative impact on the economic condition of the country. He stressed that people of his age are exhausted as a result of the system and organization of work in communist Poland and the fact that many countries in Western Europe have a shorter working week than Poland, which leads to better health and the possibility of working longer and retiring at an older age. Wojciech Zubowski (PiS) also focused on the worse health condition of those over the age of 60 in Poland compared to other countries. He cited OECD data from 2013 which showed that 
only $15 \%$ of Poles regarded their health as good or very good, which would allow them to work, compared to $50 \%$ in the UK and almost $60 \%$ in the Netherlands. In his answer, Dombrovskis stressed that in Commission's view high participation in the labour market and economic growth should be ensured and that lowering the statutory retirement age could undermine the future of the pension system.

The fact that this sub-section of CSR was contested by the MPs did not lead to the Commission changing it in the following year. In fact, while the overall CSR was changed and its implementation increased from 'no progress' to 'limited progress,' when it comes to the contested subrecommendation, it appeared again. What is more, the most contested issue (the demand to increase the retirement age) appeared in the CSR the next year expressis verbis, which means that not only did the Commission not change its behaviour according to the wishes of the MPs, it even strengthened its stance towards this contested issue. Thus, the contestation of this CSR did not lead to policy change, both in terms of actor's behaviour or its implementation.

Out of four questions about three specific sub-CSRs, the Commission dropped two of them in the following year (on the fiscal council and on the better VAT compliance), but those were not contested. The only one which was contested did lead to a change, but not in the direction hoped for by the MPs, as the sub-CSR in 2017 on the pension reform was even strengthened and explicitly demanded "measures to increase the effective retirement age" (European Commission, 2018, p. 12)the exact policy measure that the MPs had opposed a few months earlier. When it comes to a link between ownership and implementation, in the sub-CSRs concerning pension system, no change in the implementation level could be observed ('no progress' in both 2016 and 2017); one sub-CSR on the fiscal council was dropped (but was not implemented); and the third, on VAT compliance, was dropped, perhaps as a result of improved implementation (cf. European Commission, 2018, pp. 15-18). Those preliminary findings seem to suggest that the link between ownership and implementation is limited at best and that the influence of NPs on the Commission is even weaker.

\section{Conclusions}

This article demonstrates that an innovative form of accountability in the context of non-euro states can be exercised in a way that enhances the accountability of the actor. But for this to succeed, both the forum and the actor need to fulfil some requirements. On the one hand, the MPs should ask questions that relate to the area of responsibilities of the Commissioner that is held to account. On the other hand, the actor being held to account should engage in a meaningful way with the forum. They should answer the questions fully with as much detail as the format of the hearing allows, and should not evade them by providing hollow, generalised answers. The quality of the interactions shows that the Commission has tried to increase the low level of implementation of the CSRs by engaging with the members of the Sejm. The idea (also expressed by Dombrovskis in one of the hearings when he said that the main means to ensure that CSRs are implemented are dialogue with NPs and their promotion in a given country) is that the greater the 'ownership' by MPs, the higher their implementation level. However, this article shows that the strength of the relationship between those two factors may be exaggerated. In sum, according to the conditions of accountability employed for this study and outlined in the Analytical Framework Section, we may conclude that the Commission is accountable to this national parliament. This is true even if the form of accountability taken is mainly justification (only quarter of the interactions fell within the 'heavier' form of accountability, i.e., contestation) and its policy impact limited, at both the EU (the CSRs tend to be immune to MPs' criticism) and the national level, as the implementation of CSRs seems to be independent of the level of their scrutiny, at least in this particular case.

\section{Acknowledgments}

This research was supported by funding from the European Research Council under the European Union's Horizon 2020 research and innovation programme (grant agreement no. 716923). I am particularly grateful for helpful comments I received on this article to Mark Dawson, Aleksandra Maatsch, the two anonymous reviewers, as well as the participants of the European Governance Colloquium of 2 March 2020 and the "ERC Workshop-Rising to a Challenge? 10 Years of Parliamentary Accountability of Post-Crisis EU Economic Governance" of 10 December 2020, both held at the Hertie School, Berlin. The usual caveat applies.

\section{Conflict of Interests}

The author declares no conflict of interests.

\section{References}

Auel, K. (2007). Democratic accountability and national parliaments: Redefining the impact of parliamentary scrutiny in EU affairs. European Law Journal, 13(4), 487-504.

Auel, K., \& Höing, O. (2014). Parliaments in the euro crisis: Can the losers of integration still fight back? Journal of Common Market Studies, 52(6), 1184-1193.

Auel, K., Rozenberg, O., \& Tacea, A. (2015). Fighting back? And, if so, how? Measuring parliamentary strength and activity in EU affairs. In C. Hefftler, C. Neuhold, O. Rozenberg, \& J. Smith (Eds.), The Palgrave handbook of national parliaments and the European Union (pp. 60-93). Palgrave Macmillan. 
Barrett, G. (2015). Long train running: The slowly developed (and slowly developing) role of Ireland's Oireachtas in EU affairs. In C. Hefftler, C. Neuhold, O.Rozenberg, \& J. Smith (Eds.), The Palgrave handbook of national parliaments and the European Union (pp. 290-311). Palgrave Macmillan.

Benz, A. (2013). An asymmetric two-level game. Parliaments in the euro crisis. In B. Crum \& J. E. Fossum (Eds.), Practices of inter-parliamentary coordination in international politics: The European Union and beyond (pp. 125-143). ECPR Press.

Benz, A. (2006). Policy-making and accountability in EU multilevel governance. In A. Benz \& Y. Papadopolous (Eds.), Governance and democracy: Comparing national, European and transnational experiences (pp. 99-115). Routledge.

Bergman, T., \& Damgaard, E. (Eds.). (2000). Delegation and accountability in European integration: The Nordic parliamentary democracies and the European Union [Special Issue]. Journal of Legislative Studies, 6(1).

Bergman, T., Müller, W., Strøm, K., \& Blomgren, M. (2003). Democratic delegation and accountability: Cross-National Patterns. In K. Strøm, W. Müller, \& T. Bergman (Eds.), Delegation and accountability in parliamentary democracies (pp. 109-220). Oxford University Press.

Bovens, M., Schillemans, T., \& Goodin, R. E. (2014). Public accountability. In M. Bovens, R. Goodin and T. Schillemans (Eds.), The Oxford handbook of public accountability (pp. 1-22). Oxford University Press.

Busuioc, M., \& Lodge, M. (2016). The reputational basis of public accountability. Governance, 29(2), 247-263.

Crum, B. (2018). Parliamentary accountability in multilevel governance: What role for parliaments in postcrisis EU economic governance? Journal of European Public Policy, 25(2), 268-286.

Crum, B., \& Oleart, A. (2020). Accountability and transparency in a multilevel polity: European commissioners in national parliaments (Reconnect Working Paper). Leuven Centre for Global Governance Studies. https://reconnect-europe.eu/wp-content/ uploads/2021/01/D6.3.pdf

Darvas, Z., \& Leandro, A. (2015). The limitations of economic policy coordination in the euro area under the European Semester (Bruegel Policy Contribution No. 2015/19). Bruegel.

Dawson, M. (2015). The legal and political accountability structure of 'post-crisis' EU economic governance. JCMS: Journal of Common Market Studies, 53(5), 976-993.

Eriksen, A., \& Katsaitis, A. (2020). Accountability through mutual attunement: How can parliamentary hearings connect the elected and the unelected? Public Policy and Administration. Advance online publication. https://doi.org/10.1177/0952076720977606

European Commission. (2017). Country report Poland
2017 (SWD(2017) 86 final). https://ec.europa.eu/ info/sites/default/files/2017-european-semestercountry-report-poland-en.pdf

European Commission. (2018). Country report Poland 2018 (SWD(2018) 219 final). https://ec.europa.eu/ info/sites/default/files/2018-european-semestercountry-report-poland-en_1.pdf

European Parliament. (2018). Report on the European Semester for economic policy coordination: Annual growth survey 2018 (2017/2226(INI)). https://www. europarl.europa.eu/doceo/document/A-8-20180047_EN.pdf

Fabbrini, S. (2021). Who holds the elephant to account? Executive power political accountability in the EU. Journal of European Integration. Advance online publication. https://doi.org/10.1080/07036337.2021. 1915304

Fasone, C. (2015). Taking budgetary powers away from national parliaments? On parliamentary prerogatives in the eurozone crisis (EUI LAW Working Paper No. 3). European University Institute. http://hdl. handle.net/1814/36658

Fasone, C. (2018). Has euro-crisis law affected the power balance in national parliaments? A comparative analysis on the role of committees. Politique européenne, 59(1), 24-57.

Fromage, D. (2017). Executive accountability to national parliaments in post-crisis EU affairs: The persistent shortcomings in the Council and European Council oversight. In D. Jancic (Ed.), National parliaments after the Lisbon Treaty and the euro crisis resilience or resignation? (pp. 159-176). Oxford University Press.

Haas, J. S., D'Erman, V., Schulz, D., \& Verdun, A. (2020). Economic and fiscal policy coordination after the crisis: Is the European Semester promoting more or less state intervention? Journal of European Integration, 42(3), 327-344.

Hagelstam, K., Lehofer, W., \& Ciucci, M. (2018). The role of national parliaments in the European Semester for economic policy coordination: In-depth analysis. European Parliament. https://www.europarl.europa. eu/RegData/etudes/IDAN/2018/614494/IPOL_ IDA(2018)614494_EN.pdf

Hallerberg, M., Marzinotto, B., \& Wolff, G. (2018). Explaining the evolving role of national parliaments under the European Semester. Journal of European Public Policy, 25(2), 250-267.

Hefftler, C., Neuhold, C., Rozenberg, O., \& Smith, J. (Eds.). (2015). The Palgrave handbook of national parliaments and the European Union. Palgrave Macmillan.

Jancic, D. (2011). National parliaments and European constitutionalism: Accountability beyond borders [Doctoral thesis, Utrecht University]. Utrecht University Repository. http://dspace.library.uu.nl/handle/ $1874 / 211177$

Jancic, D. (2016). National parliaments and EU fiscal integration. European Law Journal, 22(2), 225-249.

Kohler-Koch, B., \& Rittberger, B. (2007). Debating the 
democratic legitimacy of the European Union. Rowman \& Littlefield.

Kreilinger, V. (2016). National parliaments, surveillance mechanisms and ownership in the euro area. Jacques Delors Institute. https://institutdelors.eu/ en/publications/national-parliaments-surveillancemechanisms-and-ownership-in-the-euro-area

Lord, C. (2014). On the parliamentary control of a reformed monetary union? In J. E. Fossum \& A. Menendez (Eds.), The European Union in crises or the European Union as crises? ARENA. https://www.sv. uio.no/arena/english/research/publications/arenareports/2014/report-2-14.pdf

Maatsch, A. (2017a). Effectiveness of the European Semester: Explaining domestic consent and contestation. Parliamentary Affairs, 70(4), 691-709.

Maatsch, A. (2017b). Parliaments and the economic governance of the European Union: Talking shops or deliberative bodies? Routledge.

MacCarthaigh, M. (2007). Accountability through national parliaments: Practice and problems. In J. O'Brennan \& T. Raunio (Eds.), National parliaments within the enlarged European Union: From 'victims' of integration to competitive actors? (pp. 29-45). Routledge.

Maurer, A., \& Wessels, W. (Eds.). (2001). National parliaments on their ways to Europe: Losers or latecomers? Nomos.

Pernice, I. (2017). Financial crisis, national parliaments, and the reform of the Economic and Monetary Union. In D. Jancic (Ed.), National parliaments after the Lisbon Treaty and the euro crisis resilience or resignation? (pp. 115-140). Oxford University Press.

Raunio, T. (2001). The Parliament of Finland: A model case for effective scrutiny? In A. Maurer \& W. Wessels (Eds.), National parliaments on their ways to Europe: Losers or latecomers? (pp. 173-198). Nomos.

Schmidt, V. (2004). Europeanization of national democracies: The differential impact on simple and compound polities. Politique Européenne, 2(13), 115-142.

Schweiger, C. (2021). Parliamentary scrutiny of the European Semester: The case of Poland. Politics \& Governance, 9(3), 124-134.
Sejm. (2013a). Full record of the course of the meeting European Union Affairs Committee (No.128).

Sejm. (2013b). Full record of the course of the meeting European Union Affairs Committee (No.160), Public Finance Committee (No. 177), Economic Committee (No. 58).

Sejm. (2014a). Full record of the course of the meeting European Union Affairs Committee (No.220).

Sejm. (2014b). Full record of the course of the meeting European Union Affairs Committee (No.257), Public Finance Committee (No. 331), Economic Committee (No. 112).

Sejm. (2017). Full record of the course of the meeting European Union Affairs Committee (No.117), Public Finance Committee (No. 182), Economic and Development Committee (No. 66).

Sejm. (2018). Full record of the course of the meeting European Union Affairs Committee (No.246), Public Finance Committee (No. 399), Economic and Development Committee (No. 134).

Serowaniec, M. (2016). Parlamentarne Komisje do Spraw Europejskich [Parliamentary European Union Affairs Committees]. Wydawnictwo Sejmowe.

Tesche, T. (2019). Instrumentalizing EMU's democratic deficit: The ECB's unconventional accountability measures during the eurozone crisis. Journal of European Integration, 41(4), 447-463.

Vanheuverzwijn, P., \& Crespy, A. (2018). Macroeconomic coordination and elusive ownership in the European Union. Public Administration, 96(3), 578-593.

Wouters, J., \& Raube, K. (2012). Seeking CSDP accountability through interparliamentary scrutiny. The International Spectator, 47(4), 149-163.

Woźniakowski, T. P., Maatsch, A., \& Miklin, E. (2021). Rising to a challenge? Ten years of parliamentary accountability of the European Semester. Politics \& Governance, 9(3), 96-99.

Woźniakowski, T. P., Schimmelfennig, F., \& Matlak, M. (2018). Europeanization revisited: An introduction. In M. Matlak, F. Schimmelfennig, \& T. P. Woźniakowski (Eds.), Europeanization revisited: Central and Eastern Europe in the European Union (pp. 6-18). Robert Schuman Centre for Advanced Studies.

\section{About the Author}

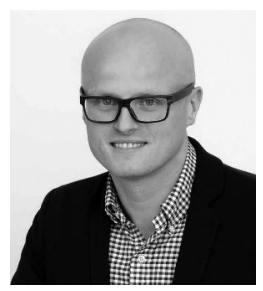

Tomasz P. Woźniakowski is a Doctor of Political and Social Sciences of the European University Institute (Florence), a Post-Doctoral Researcher for Leviathan, an ERC-funded project at the Hertie School, and a Lecturer at Stanford University (Berlin). His research focuses on the US and EU fiscal unions in a comparative historical perspective and parliamentary accountability in EU economic governance. 